\title{
SOME CONSTITUTIONAL CONSIDERATIONS ON SEXUAL VIOLENCE AGAINST WOMEN
}

\author{
DR. SHEILAH L. MARTIN
}

In this article, the author examines the ways in which women's constitutional rights can, and should, inform our understanding of sexual violence and mandate its proper treatment by the courts. The author argues that a purposive analysis of the rights guaranteed by 5.7 imposes an obligation on the state to protect women's lives, liberty, and physical and mental security against sexual violence. At the same time, the equality provisions of ss. 15 and 28 require that the gender specificity of sexual violence, and its relation to the larger social context of women's inequality, be addressed, with the result that sexual assault is recognized as a form of sex discrimination. Through decisions such as R. v. McCraw, determinations of women's individual and groupbased rights, in light of their social context, are shown to be essential to a full realization of the Charter's claims to equality and to life, liberty and security of the person.
L'auteure examine comment les droits constitutionnels de la femme peuvent - et devraient - approfondir notre compréhension de la violence sexuelle et dicter la façon dont elle traitée par les tribunaux. L'auteure soutient qu'une analyse raisonnée des droits garantis par l'article 7 impose à l'État l'obligation de protéger la vie, la liberté et la sécurité physique et mentale de la femme contre la violence sexuelle. En même temps, les dispositions d'égalité des paragraphes 15 et 28 exigent que soient pris en ligne de compte la spécificité de la violence sexuelle et ses rapports au contexte plus vaste d'inégalité de la femme. Il s'ensuit que les agressions sexuelles doivent être reconnues comme une forme de discrimination sexuelle. Grâce aux décisions comme celles de R. c. McCraw, la détermination des droits individuels et collectifs de la femme, pris dans leur contexte social, s'avère essentielle à la pleine réalisation des garanties de la Charte concernant le droit à l'égalité et à la vie, à la liberté et à la sécurité de la personne.

\section{TABLE OF CONTENTS}

I. INTRODUCTION ..................... 535

II. THE SCOPE AND APPLICATION OF

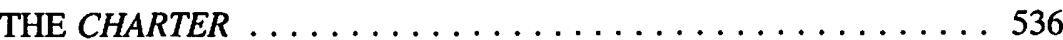

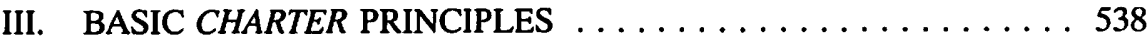

IV. RELEVANT CHARTER RIGHTS: INDIVIDUAL

RIGHTS UNDER SECTION $7 \ldots \ldots \ldots \ldots \ldots \ldots \ldots$

V. RELEVANT CHARTER RIGHTS:

EQUALITY RIGHTS . . . . . . . . . . . . . . . . . . . 547

VI. APPLYING CHARTER RIGHTS TO

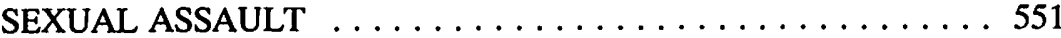

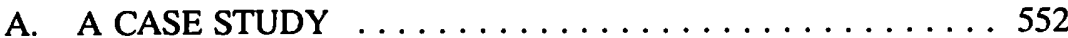

B. SOME FURTHER THOUGHTS $\ldots \ldots \ldots \ldots \ldots \ldots \ldots 554$

VII. CONCLUSION $\ldots \ldots \ldots \ldots \ldots \ldots \ldots \ldots \ldots \ldots \ldots \ldots \ldots$

\section{INTRODUCTION}

The past twenty-five years have seen significant changes in the goals and content of the Criminal Code's treatment of sexual violence. Conceptual shifts in the way in which sexual violence is categorized and understood have led to waves of legislative reform and 
judicial reinterpretation. The future direction of laws on sexual assault will be influenced by new considerations and principles because the Charter of Rights and Freedoms ${ }^{1}$ has so fundamentally altered legal discourse in Canada. The Charter rights of the criminal accused, both generally and in relation to sexual assault, have been the subject of a great quantity of legal literature and much litigation. In comparison, little attention has been paid to the constitutional interests of the victims of sexual assault, most of whom are women. This is rather surprising because the Charter rights of women have an important role to play in the formulation, application and interpretation of sexual assault laws.

In this paper, I reveal some of the Charter's wide ranging implications for sexual assault laws. First, I canvass the scope and application of the Charter. Secondly, I outline certain basic Charter principles to provide the backdrop for how particular Charter interests may shape this area of the criminal law. I then explore women's individual rights under s. 7 and women's group based equality rights under ss. 15 and 28. Finally, I use the Supreme Court decision in $\mathrm{R}$. v. $\mathrm{McCraw}^{2}$ to illustrate how the gender inclusive norms mandated by the Charter can be incorporated within the existing framework of the criminal law. I argue that using women's Charter rights as an organizing principle behind the criminalization of sexual assault has numerous consequences and may result in a prohibition that more truly condemns sexual violence and more fully values women's physical integrity, sexual autonomy and sex equality.

\section{THE SCOPE AND APPLICATION OF THE CHARTER}

The Charter applies to state action and state actors but does not directly or comprehensively govern private relationships. ${ }^{3}$ State actors include legislators, members of the executive and perhaps even judges. On some sexual assault issues, finding state action may be problematic because the direct physical invasion of the victim is usually done by a private person or non-state actor. However, the criminal laws which deal with sexual assault are forms of state action and are subject to Charter guarantees. Even if one does not see judges, lawyers and police officers as state actors in the full sense of that term, they are nevertheless obliged to exercise their legally sanctioned discretion in a manner consistent with Charter rights. ${ }^{4}$

The three principal sections of the Charter that bear most directly on state action concerning sexual assault are ss. 7,15 and $28 .{ }^{5}$ Taken together, these guarantees require

Part I of the Constitution Act, 1982, being Schedule B of the Canada Act 1982 (U.K.), 1982, c. 11 [hereinafter the Charter].

(1991), 66 C.C.C. (3d) 517 (S.C.C.).

See R.W.D.S.U. loc. 580 v. Dolphin Delivery Ltd., [1986] 2 S.C.R. 573. But Mr. Justice McIntyre recognizes the application of the Charter to such private relations "[w]here such exercise of, or reliance upon, governmental action is present and where one private party invokes or relies upon it to produce an infringement of the Charter rights of another" at 602-03.

For an interesting argument of what constitutes state action see C.A. MacKinnon, Towards a Feminist Theory of the State (Cambridge: Harvard University Press, 1989).

Section 7 states "Everyone has the right to life, liberty and security of the person and the right not to be deprived thereof except in accordance with the principles of fundamental justice." 
state actors to safeguard the security of women in such a way, and to such an extent, that women are both equal, and equally free, in our free and democratic society. This may entail obligations of various intensities because there are many ways in which women's Charter rights bear on the law of sexual assault. For example, state action which fails to respect women's rights may be impugned directly. ${ }^{6}$ Or women's Charter rights may operate to help insulate certain provisions from constitutional challenge. ${ }^{7}$

A more controversial suggestion is that the state must actively create and rigorously enforce policies and procedures designed to promote the equal liberty and security of women's persons. Or, consider the argument that the state is under a positive obligation to establish offences or allocate resources in a manner which minimizes the risks of violence to women. ${ }^{8}$ It is even suggested that "unequal resources may have to be directed towards such offences to ensure an actual equal right to liberty and security of the person.." ${ }^{19}$ Supreme Court case law on equality contemplates that, because of women's unequal and disproportionate burden of sexual victimization, the state response should correspond to the demonstrated need. ${ }^{10}$ Even if these directions are not followed fully, at the very least women's constitutional rights must be used to construe and apply existing legislative provisions and to inform current legal concepts. Most of the following discussion concerns this basic level of constitutional conformity."

Section 15(1) states "Every individual is equal before and under the law and has the right to the equal protection and equal benefit of the law without discrimination and, in particular, without discrimination based on race, national or ethnic origin, colour, religion, sex, age or mental or physical disability."

Section 28 states "Notwithstanding anything in this Charter, the rights and freedoms referred to in it are guaranteed equally to male and female persons."

- For example, the old statutory exemption which excluded marital rape from the purview of the otherwise general criminal prohibition against rape would have been an obvious subject for a direct challenge. See C. Boyle, "Married Women-Beyond the Pale of the Law of Rape" (1981) Windsor Y.B. Access Just. 192.

7 This approach was used in R. v. Butler (1992), 89 D.L.R. (4th) 449 (S.C.C.), where the Supreme Court accepted women's equality rights as a basis for upholding the criminal prohibition against obscenity under s. 1 even though it infringed freedom of expression. This approach was also used in $R$. v. Seaboyer; $R$. v. Gayme (1991), 66 C.C.C. (3d) 321 (S.C.C.) [hereinafter Seaboyer] where it was argued that the statutory limits on questions concerning the victim's prior sexual history could be justified on the basis of the equality interests of women. This argument failed to persuade the majority of the Supreme Court, who did not classify what was at stake for women as involving important and wide ranging matters such as physical integrity and equality interests. The majority took an extremely narrow view of women's interests and downplayed them by speaking about women being embarrassed by disclosure. In contrast, the equality perspective formed an integral part of the dissenting judges' reasoning and probably explains the divergence in the results. For comments on this sort of evidence see E. Sheehy, "Canadian Judges and the Law of Rape: Should the Charter Insulate Bias?" (1989) 21 Ottawa L. Rev. 151; Y.A. Grant, "The Penetration of the Rape Shield" (1989-90) 3 C.J.W.L. 592.

$9 \quad$ Ibid. at 38. Boyle continues at 40: "[t]he idea that the Charter requires the re-allocation of state resources toward the protection of women in order to ensure equal liberty and security of the person may be viewed by some as a romantic rather than realistic argument, but at the very least it puts into perspective the change to a gender-neutral sexual offence law." 


\section{BASIC CHARTER PRINCIPLES}

Before exploring particular Charter sections, it is important to understand that the Charter is a purposive document. Its mandate "is to provide . . . for the unremitting protection of individual rights and liberties"12 and it is "first and foremost an effects oriented document." ${ }^{13}$ The Charter seeks to ameliorate group disadvantage and enshrines equality, especially sex equality, as an organizing principle of Canadian democracy. ${ }^{14}$ Due to its remedial focus, the rights it protects and the guarantees it provides must be interpreted generously and with the objective of ensuring for individuals the full benefit of its protection.

Women across the country fought hard for, and eventually obtained, the entrenchment of sex equality rights in the Charter. To the extent that "[t]he Constitution of a country is a statement of the will of the people to be governed in accordance with certain principles held as fundamental and certain prescriptions restrictive of the powers of the legislature and government,"15 Canadian women wanted to participate as full and equal citizens in Canadian society and to be brought fully into the constitutional fold of legally enforceable rights. The barriers women encountered in the protracted and painful process of constitutional inclusion are themselves evidence of sex inequality. ${ }^{16}$ They also illustrate the difficulty women have traditionally encountered when attempting to secure legal provisions which include them. Under a purposive analysis of the Charter, the political energy which secured women's inclusion in the Charter must flow through to the interpretation of individual Charter provisions. Only in this way will women's needs and aspirations be translated into constitutionally recognized rights and, in turn, shape all forms of state action - including legislation on sexual assault.

The constitutional status and remedial content of the Charter have also focused attention on some larger and persistent jurisprudential questions, including the role law plays in creating, maintaining and possibly changing various social hierarchies. There is a large body of legal literature that explores the biases and partiality of law and uncovers

Hunter v. Southam, [1984] 2 S.C.R. 145 at 155 where the Court explained that the purpose of the Charter is to guarantee and to protect, within the limits of reason, the enjoyment of the rights and freedoms that it enshrines. It is intended to constrain governmental action inconsistent with those rights and freedoms.

$13 \quad$ R. v. Big M Drug Mart Ltd., [1985] 1 S.C.R. 295 at 360 per Wilson J.

14 Dickson, C.J. in R. v. Edwards Books and Art Ltd., [1986] 2 S.C.R. 713 at 779 said: "In interpreting and applying the Charter I believe that the courts must be cautious to ensure that it does not simply become an instrument of better situated individuals to roll back legislation which has as its object the improvement of the condition of less advantaged persons."

Reference Re Language Rights Under s. 23 of Manitoba Act, 1870 and s. 133 of the Constitution Act, 1867, [1985] 1 S.C.R. 721 at 745.

16 C. Hosek, "Women and the Constitutional Process" in K. Banting \& R. Simeon, eds., And No-One Cheered: Federalism, Democracy and the Constitutional Act (Methuen: Toronto, 1983) 280; P. Kome, The Taking of Twenty-Eight (Women's Press: Toronto, 1983); L. Gotell, The Canadian Women's Movement, Equality Rights and the Charter (Ottawa: C.R.I.A.W., 1990). See generally A. Doerr \& M. Carrier, eds., Women and the Constitution (Ottawa: Canadian Advisory Council on the Status of Women, 1981). 
the political choices encoded in law's apparent "point-of-viewlessness". ${ }^{17}$ To the extent that law either is, or is about, politics and power, there can be no doubt that law has played a significant and complex role in reinforcing gender based and other power imbalances. ${ }^{18}$ If law is seen as an artifact of human agency, it can be used to pursue various goals, including the promotion of egalitarian ideals. Using the Charter as a means to encourage progressive social change is one aspiration of equality seeking Canadians. ${ }^{19}$

The formal inclusion of women as full rights bearers under the Charter is an important step in this progression. Under the Charter, we are required to ask and answer a whole new set of constitutional questions and to change the content of heretofore "established" rights and freedoms. Previously excluded groups often formulate new questions which the existing power structure is bound, even according to its own norms, to take seriously. For example, do general rights to liberty and security of the person include a woman's ability to obtain an abortion? What does self defence mean to a battered woman? How can we create legal norms of equality for all women when we live in a society structured by inequalities, including those of gender, race and class? How can the law on sexual assault respect women's rights, safeguard women's bodies and include women's diverse perspectives? These are particular variations of the general question of what will constitutional rights look like now that women are supposed to have them too.

If we understand the extent and effects of women's prior exclusion and the complex role of law in reflecting and consolidating that exclusion, it should come as no surprise that the answers to these new questions may look like nothing we have seen before. This may generate some concern in a precedent based legal system. But the Charter now requires state actors to fashion gender inclusive norms where necessary and to question whether certain existing concepts are largely male-defined.

See MacKinnon, supra note 4 where she refers to this as a false "point-of-viewlessness". See also S. Gavigan, "Law, Gender and Ideology" in A. Bayefsky, ed., Legal Theory Meets Legal Practice (Edmonton: Academic Printing and Publishing, 1988); K. O'Donovan, Sexual Divisions in Law (London: Weindenfeld and Nicholson, 1985); S. McLean \& N. Burrows, eds., The Legal Relevance of Gender (New Jersey: Humanities Press, 1988); C.A. MacKinnon "Feminism, Marxism, Method and the State: Towards a Feminist Jurisprudence" (1984) 8 Signs 635; J. Rifkin, "Toward a Theory of Law and Patriarchy" (1980) 3 Harvard W.L.J. 83; D. Polan, "Towards a Theory of Law and Patriarchy" in D. Kairys, ed., The Politics of Law (New York: Pantheon, 1982) 294; A. Scales, "Toward a Feminist Jurisprudence" (1981) 56 Ind. L.J. 375; C. Littleton, "Reconstructing Sexual Equality" (1987) 75 Cal. L.R. 1279; K. O'Donovan, "Engendering Justice: Women's Perspectives and the Rule of Law" (1989) 29 U.T.L.J. 127.

There are many and varied ways in which gender bias has manifested itself in law. In many cases there is the unstated use of the male body as the baseline for comparison, where the male reaction is improperly used as the litmus test for "everyone". In other cases the law may preserve and protect a predominantly male interest or fail to recognize or properly value the harms suffered by women because they are suffered by women. This androcentricity has been uncovered and criticized in many areas of the law and it is especially apparent in relation to crimes of sexual assault.

19 There is a risk, however, that, regardless of the promise of the Charter, the fact that women's needs in the context of sexual assault are concrete, specific and real, means they may not be adequately transposed into a legal language where the dominant concepts have been the largely abstract and heretofore male-defined notions of rights and freedoms. 
There are signs that this process of critical review and creative rewriting has already begun. ${ }^{20}$ In defining women's constitutional rights, the Supreme Court has recognized the challenge of fashioning legal principles which include all aspects of women's experience, especially those parts of a woman's life, like pregnancy or sexual violability, which are not experienced in the same way by men. In a Charter challenge to a criminal prohibition against abortion, Madame Justice Wilson incorporated the following remarks into her judgment:

...the history of the struggle for human rights from the eighteenth century on has been the history of men struggling to assert their dignity and common humanity against an overbearing state apparatus. The more recent struggle for women's rights has been a struggle to eliminate discrimination to achieve a place for women in a man's world, to develop a set of legislative reforms in order to place women in the same position as men... It has not been a struggle to define the rights of women in relation to their special place in the societal structure and in relation to the biological distinction between the two sexes. Thus, women's needs and aspirations are only now being translated into protected rights. ${ }^{21}$

The Supreme Court has taken gender specific realities into account in non-constitutional cases as well. In the criminal context, in $R$. v. Lavallee ${ }^{22}$ the Court admitted expert evidence on the battered women's syndrome to determine whether the accused, who shot and killed a man who had physically abused her in an ongoing relationship, had the requisite "reasonable apprehension of death or grievous bodily harm" to successfully plead self-defence. ${ }^{23}$ Madame Justice Wilson ${ }^{24}$ considered the woman's sex-specific physical and social realities and defined the legal issue in relation to her physical abuse and psychological victimization..$^{25}$ She questioned the relevance of applying the habitual and objective standard of the ordinary man to an abused woman. She held that what is reasonable must be adapted to the person's actual life circumstances and that this form of violence is foreign to the world inhabited by the hypothetical "reasonable man". ${ }^{26}$ This type of judicial statement represents the beginning of the egalitarian approach required because of, and under, the Charter.

For a general review of whether the whole thinking behind the criminal law is male-defined, see $\mathrm{C}$. Boyle et al., A Feminist Review of the Criminal Law (Ottawa: Supply and Services Canada, 1985); L. Sheehy, Personal Autonomy and the Criminal Law: Emerging Issues for Women (Ottawa: Canadian Advisory Council on the Status of Women, 1987). Morgentaler, Smoling et al. v. The Queen, [1988] 1 S.C.R. 30 at 171-72. Madame Justice Wilson was citing from N. Burrows, "International Law and Human Rights: The Case of Women's Rights" in T. Campbell et al., eds., Human Rights: From Rhetoric to Reality (Oxford: Blackwell, 1986) at 81-82. [1990] 1 S.C.R. 852.

Criminal Code, R.S.C. 1985, c. C-46, s. 34(2).

She wrote for herself, Dickson C.J., Lamer, L'Heureux-Dubé, Gonthier, and McLachlin JJ. Sopinka J. concurred in the result but provided further reasons.

25 Supra note $\mathbf{2 2}$ at $\mathbf{8 8 3}$ she commented: "I do not think that it is an unwarranted generalization to say that due to their size, strength, socialization and lack of training, women are typically no match for men in hand-to-hand combat." discipline his wife and how this may have established the groundwork for the persistent myths about wife battering and stereotypes of women in abusive relationships. 


\section{RELEVANT CHARTER RIGHTS: INDIVIDUAL RIGHTS UNDER SECTION 7}

Sexual assault, which may be defined as non consensual, sexually motivated conduct, is both sex and violence. ${ }^{27}$ This combination means that all three of the victim's $\mathbf{s} .7$ Charter rights are implicated whenever a sexual assault occurs. For s. 7 to receive a purposive interpretation, its three rights of life, liberty and security of the person should be defined according to the interests they were intended to protect. ${ }^{28}$

First, sexual assault threatens the victim's right to life in direct and indirect ways. Most obviously, the right is infringed if death results and death for women often occurs within the context of sexual violence. ${ }^{29}$ However, sexual assault has been called:

an act of aggression in which the victim is denied her self determination. It is an act of violence which, if not actually followed by beatings or murder, nevertheless always carries with it the threat of death. ${ }^{30}$

Properly defined there can be no doubt that sexual assault, whatever its form, is violence with sex as the weapon. This means that the harms sexual assault is seen to generate should, at a minimum, be those accorded to all violent conduct. The structure of the Criminal Code offences recognizes this but provides that in certain circumstances, additional violence aggravates and increases the seriousness of the core offense. There is a debate on whether sexual assault is either primarily violence or fundamentally sex. Although the issue should not be seen in these strictly dichotomous terms, there is an historical explanation of this division. In the late 1970s, the violent aspects of rape were emphasized in an attempt to explain the harms of rape and to obtain Criminal Code provisions which more genuinely reflected women's needs. In 1982, the debate was framed in such a way as to convince legislators and the public of the seriousness of rape. To do so, the analogy to other assaults was made and eventually accepted. There are, however, problems if one forgets that the assault is also definitionally sexual and that this crime is characterized by the commingling of aggression and sex. See MacKinnon, supra note 4 at 126. It is interesting to note that in $R$. v. Chase, [1987] 2 S.C.R. 293 the Supreme Court, in defining the term sexual, did not require that the activities be for the sexual gratification of the accused. This is an implicit recognition that a sexual assault can be committed for other than sexual reasons.

In Singh v. Minister of Employment and Immigration, [1985] 1 S.C.R. 177 the Supreme Court decided that it is sufficient to show a breach of any one of these interests to establish an infringement of a s. 7 right. As its wording indicates, $s .7$ allows infringements on the right to life, liberty, and security of the person as long as those infringements accord with the rules of fundamental justice. A threat to a specified interest is sufficient to establish a breach. There may also be an argument that the term "life" in $\mathbf{s .} 7$ is not limited to the concept of physical existence. It may have a more expansive meaning, such that the right to life may be more than a preventive against death, although it would contain that at a minimum. To the extent that the term "life" contains and connotes a right to a certain type of life, for example, an equal life, one worth living or one worth living on one's own terms, then its relevance to women and physical security is increased. In 1988, $4.5 \%$ of all homicides in Canada were committed during a sexual assault. This rate was slightly higher than the previous ten year average of $3.8 \%$, and was the highest in six years, despite the fact that the murder rate was at its lowest since 1971 and was $16 \%$ lower than the previous ten year average. Of the $19.1 \%$ of homicides committed during other criminal acts in 1988, 23.6\% of those other offences were sexual assaults. See Statistics Canada, Canadian Centre for Justice Statistics, Homicide in Canada: 1988, A Statistical Perspective (Ottawa: Supply and Services, 1989) at 15,53 . 
The experience generally carries the fear of death because once control is taken from the woman, there is often no stopping point short of the expectation of annihilation.

Secondly, even though the precise content of the right to liberty has not yet been comprehensively defined, liberty has long been recognized as a fundamental value in our free and democratic society. ${ }^{31}$ That sexual assault denies the victim's liberty interest, however constituted or defined, is apparent. Sexual assault involves invasion, confinement and physical violation by force. It involves restriction and represents the ultimate disrespect - the denial of another person's power of consent. According to the Supreme Court in $R$. v. $M c C r a w,{ }^{32}$ sexual violence deprives women of their liberty and denies their personal inviolability in a most frightening, profound and intimate manner:

For women, rape under any circumstance must constitute a profound interference with their physical integrity. As well, by force or threat of force, it denies women the right to exercise freedom of choice as to their partner for sexual relations and the timing of those relations. These are choices of great importance that may have a substantial effect on the life and health of every woman. ${ }^{33}$

Sexual assault also generates particular harms that may restrict the victim's liberty even after the assault. For example, the physical terms of the attack are supposed to be associated with intimacy and affection and this may increase the severity of the attack and its physical and psychological consequences in distinctive ways. ${ }^{34}$

Third, the remaining s. 7 interest of security of the person is especially important in relation to sexual assault. Professor Boyle claims:

It is uncontroversial that it is overwhelmingly men who commit sexual assaults and women who are the victims of them. One result has been that women are less free "to walk, to stroll or to loaf" than men and to go about the common occupations of humanity. Men, of course, are also the victims of crimes of violence, but the fear and reality of sexual assault is a significant extra limitation on the freedom of

Disorder in DSM III - the Diagnostic and Statistical Manual of Mental Disorders which is the mainstay of psychiatric diagnosis. See A.N. Delorey, "Rape Trauma Syndrome: An Evidentiary Tool" (1989-90) 3 C.J.W.L. 531. In R. v. Oakes, [1986] 1 S.C.R. 103 at 136 Chief Justice Dickson remarked that the hallmarks of a free and democratic society were, among others: "respect for the inherent dignity of the human person, commitment to social justice and equality, accommodation of a wide variety of beliefs, respect for cultural and group identity, and faith in social and political institutions which enhance the participation of individuals and groups in society." See also R. v. Big M Drug Mart Ltd., supra note 13.

34 One consequence of a sexual assault is that women may learn to distrust their own assessment of who can be trusted and what is a safe situation. In addition, what may be especially debilitating for survivors of sexual assault is the expectation that they can, will and should put the assault behind them and continue to function as (hetero)sexual beings. After a time, the victim will generally be expected to derive pleasure from sexual acts and once again function as a sensitive and sensate partner. To put the aftermath of a sexual assault into perspective, it is important to realize that a victim of a non-sexual assault is not expected to enjoy a subsequent beating as long as it is administered by a loved one. 
movement and bodily security of women. Women have in fact less security of the person than do men in the context of sexual assault, and yet the Charter states unequivocally that they have an equal right to that security. This is a serious issue with respect to the quality of life of the women of Canada, and of the men who care about them. ${ }^{35}$

In general terms, control over one's body is recognized as an essential part of being an individual and has been referred to as the most powerful conceptual legacy of the liberal political tradition. ${ }^{36}$ More specifically, in Morgentaler, Smoling et al. v. The Queen, ${ }^{37}$ the Supreme Court held that security of the person protects physical integrity and psychological well-being.

To truly protect the physical security of a female person in an unequal and sexually stratified society, the law must therefore take into account how every day, in many ways, women's lives are shaped by fear of violence at the hands of men. There is the fear of assault, there is the fear in the assault and there is the fear that the criminal justice system will not properly vindicate the assault. For most women, these fears are taught early, learned quickly, consistently reinforced and impossible to forget.

The fear of sexual assault is a rational response to real violence. ${ }^{38}$ Statistics indicate that sexual violence is an actual threat of significant proportions. ${ }^{39}$ At least a quarter of Canadian women have been victimized and their direct experience will exacerbate the intensity and immediacy of their fear. These women will have first hand experience of why they fear and what they fear. Statistics outline the minimum incidence of this crime but they do not completely capture the depth and pervasiveness of women's fears concerning sexual violence and the constraints these fears impose on their behaviour. To

Boyle, supra note 8 at 40 .

R. Petchesky, Abortion and Woman's Choice (New York: Longman, 1984) at 2.

Supra note 21.

L. Macleod, The City for Women: No Safe Place (Ottawa: Corporate Policy Branch, Secretary of State Canada, 1989) at 8; D. Hackett, "Gender Equality: The Written Materials" prepared for the Canadian Judicial Centre for the Education Committee of the Canadian Judicial Council, May 1990 at 49. Hackett gathered the following information:

- Statistics Canada reports that in 1985 , a sexual assault was reported in Canada every 25 minutes.

. $90 \%$ of sexual assaults involve female victims.

- 1 in 4 Canadian women will be sexually assaulted at some time in their lives.

- Approximately $60 \%$ of all rapes take place in private homes.

- A Winnipeg study revealed that $63 \%$ of women were raped by men they knew, while a Canadawide study found $41 \%$ of sexual assault victims knew their assailant. Diana Russell's study found that the victim knew her attacker in $83 \%$ of the total number of rapes, including unreported rapes.

- The men who sexually assault and the women who are victims are of all ages and from every cultural, racial, religious and socio-economic background.

- $14 \%$ of women in marriages reported being raped by their husbands and $26 \%$ had been forced to endure some form of unwanted sexual activity with their husbands.

My personal assessment is that the actual incidence of sexual violence against women is much higher than the one in four figure suggests. It is a constant revelation to me that when I speak with women in circumstances where they feel able to talk, how many separate incidents of sexual coercion most women are able to recount. These incidents range along a continuum of being touched in a sexual manner without their consent through to sexual assaults involving brutal levels of force. 
live life in female form means to experience this fear: not constantly, but consistently; not every moment of every day, but often enough to remind women that they are not free. The fears associated with sexual violence are one of the defining experiences of being female and women have many conditioned and necessary responses to this form of sex discrimination.

Women understand that they are members of a gender class seen as being vulnerable. Their group affiliation marks them as potential victims, and women factor the risks associated with sexual violence into their decision-making in many ways. Women who claim to be free of sex discrimination in the work force may nevertheless move their keys into their hands when entering the parking lot; a tacit recognition that in relation to sexual violence they are targeted and victimized on the basis of their sex. ${ }^{40}$ The wide variety of sexual invasions women are subjected to, from the dehumanizing remark to unwanted sexual contact, operate as daily reminders that despite their individual integrity, accomplishments or wishes, women can be reduced quickly, dismissively and menacingly to the body parts men desire. Women also understand that women's disgust and discomfort can quickly escalate into violence against them. In these circumstances, most women want to fight back, but they probably want to be invisible more. This is sexual stereotyping in operation. It is infuriating, debilitating and frightening.

It is now widely recognized that sexual assault is the most highly under-reported of serious crimes. ${ }^{41}$ The Federal Department of Justice estimates that only forty percent of sexual assaults are reported. ${ }^{42} \mathrm{~A}$ Winnipeg study found that ninety percent of sexual assault victims do not report the crime to the police ${ }^{43}$ and front line rape crisis workers

It is not only walking to the dark parking lot which women recognize as a situation of danger, they also realize how easily mixed gender socializing can be sexualized. Women are subjected to all forms of sexual aggression because men are supposed to be on the offensive. Being a woman means a lifetime of being prepared to manage situations where she is forced to say no; of going to work, social events or the grocery store and being confronted by someone who has become "interested" in her. In a culture which encourages male sexual aggression, the woman's privacy can be easily invaded by the man's desire. His sexual interest or arousal becomes her problem and she must "deal with it" in such a way as not to be seen to be provoking violence or acting in a socially undesirable manner.

41 See generally, R. Gunn \& C. Minch, Sexual Assault: The Dilemma of Disclosure, the Question of Conviction (Winnipeg: University of Manitoba Press, 1988). Recently, the Supreme Court of Canada acknowledged women's fear of reporting violent assaults which take a sexual form. In $R$. v. Canadian Newspaper, [1988] 2 S.C.R. 122, the Court upheld the constitutionality of a mandatory publication ban of the name and other identifying information about the victim of a sexual assault despite claims that it infringed the freedom of expression of the press. The Court reasoned that the state had a compelling state interest in encouraging victims of sexual violence to report the crime and that only a mandatory ban would furnish the victim with the required level of assured privacy. (Under the statute the ban was only mandatory when requested by the victim.) The Court thus protected the dignity and privacy of the victim because "of the most serious crimes, sexual assault is one of the most unreported" (at 131). See C. Boyle, "Publication of Identifying Information About Sexual Assault Survivors: $R$. v. Canadian Newspapers Co. Ltd." (1989-90) 3 C.J.W.L. 602.

42 Solicitor General of Canada, "Female Victims of Crime" (1985) Bulletin 4 Canadian Urban Victimization Survey, at 3.

43 J. Brickman \& J. Briere, "Incidence of Rape and Sexual Assault in an Urban Canadian Population" (1980) 7:3 Int. J. Women's Stud. 197. 
suggest that only one in twenty raped women report. ${ }^{44}$ In a national study, forty-four percent of the women interviewed cited distrust of the criminal justice system as the reason they did not report a sexual assault committed against them. ${ }^{45}$

There are numerous sex specific dimensions of this under-reporting which go beyond the rather more generalized difficulties associated with the reporting of all crimes - like the limits of legal forums in providing redress for the victim; the constricted narratives allowed under legal principles of evidence; the inattention to the victim, which is partly a function of the idea that a crime is primarily a public wrong and partly the result of chronically overworked Crown Counsel; or the victim's perceived inequality in relation to the "rights" of the accused. With respect to sexual assault, women understand that there is the idealized rape victim - the composite and constructed character who merits protection. ${ }^{46}$ Women also realize that to the extent that they do not fit this idealized victim profile, they are less likely to be believed or treated with respect. Maybe this helps explain why so few "date rapes" are reported.

Aspects of the court process may also inhibit reporting. Significant attention has been paid to the more obvious problems ${ }^{47}$ the old rules on corroboration, recent complaint, and warnings to the jury, concerns over forays into the prior sexual history of the victim, the diminished credibility accorded female witnesses, and the disincentive to reporting they cumulatively pose. But there are also other subtle and powerful factors which may influence the woman's deliberations about reporting acts of sexual violence. Reporting a sexual assault means that a woman is forced to talk about her body in a sexualized way

Toronto Rape Crisis Centre, No Safe Place: Violence Against Women and Children (Toronto: Women's Press, 1985) at 80.

P. Marshal, "Sexual Assault, The Charter and Sentencing Reform" (1988) 63 C.R. 216. Gunn \& Minch, supra note 41 have identified a number of variables that are apt to affect a woman's decision about reporting a sexual assault: Victims were more likely to report assaults to the police when: (1) they blamed the assailant; (2) they received a supportive response from the first person they told about the assault; (3) they had not experienced physical or sexual violence in their backgrounds; (4) the attack was perpetrated by a stranger; (5) there were visible injuries; (6) and they resisted vigorously, thus increasing the likelihood of injury.

A brutally beaten, sexually faithful, married, middle class white woman attacked by a stranger in her own house is perhaps the most easily recognized and fully protected of potential victims. See C. Smart, Feminism and the Power of Law (London: Routledge, 1989) at 26 et seq.

For a review of some of the literature see T.B. Dawson, "Sexual Assault Law and Past Sexual Conduct of the Primary Witness" (1988) 2 C.J.W.L. 310; J.G. Hoskins, "The Rise and Fall of the Corroboration Rule in Sexual Offence Cases" (1983) 4 Can. J. Fam. L. 173; L. Vandervort, "Mistake of Law and Sexual Assault: Consent and Mens Rea" (1988) 2 C.J.W.L. 233; Canada, Department of Justice, Sexual Assault Legislation in Canada: An Evaluation: Report \#2, The New Sexual Assault Offences (Ottawa: Queen's Printer, 1973); L.O. Wener, An Examination of the New Sexual Assault Legislation (Calgary: Alberta Law Foundation, 1985); G. Ruebsaat, The New Sexual Assault Offences: Emerging Legal Issues (Ottawa: Department of Justice, 1985); R. Hinch, "Canada's New Sexual Assault Laws: A Step Forward for Women?" (1985) 9 Contemporary Crises 33; G. Chase, "An Analysis of the New Sexual Assault Laws" (1983-84) 4 Can. Women Stud. 53; L. Vandervort, "Enforcing the Sexual Assault Laws: An Analysis for Action" (1985-86) 14 Resources for Feminist Research 4:44; B.T. Dawson, "The Abrogation of Recent Complaint: Where Do We Stand Now?" (1985) 27 Crim. L.Q. 57; D.H. Doherty, "'Sparing' the Complainant Spoils the Trial" (1984) 40 C.R. (3d) 55; S. Heald, "Social Change and Legal Ideology: A Critique of the New Sexual Assault Legislation" (1985) 7 Can. Crim. Forum 117. 
to strangers, and in a situation where the strangers have the power to withhold validation. In police interviews, in the courtroom and with the doctor she must openly discuss otherwise intimate parts of her body. She must talk of her breasts, her vagina, her anus and what the accused did to these parts of her now sexualized body, and with what parts of his body. ${ }^{48}$ It is not just that women must relate the details of their violation in a situation where many people may believe they are lying but the woman's story may give pleasure in the way pornography gives pleasure. The telling of the story, especially under the potential distortions of cross-examination, may turn the woman's violation into what has been called a "pornographic vignette". ${ }^{49}$ Carol Smart claims that "the judge, the lawyers, the jury, and the public can gaze on her body and re-enact her violation in their imagination." ${ }^{\text {I0 }}$ Understanding this, and the fact that the woman is there in the flesh to experience and feel the humiliation, illustrates how the statement that for the victim the trial is a second violation, is more than metaphor.

As a constitutional concept, security of the person is fundamentally concerned with the body and may therefore encourage an appreciation of the actual fears and harms women experience in relation to sexual assault. ${ }^{51}$ To deny someone's security of the person conjures up images of assault, force and invasion, the very things which women are forced to endure when sexually violated. Security of the person also promotes a contextual analysis, which takes into account that these intrusions often happen in and to female bodies, and the persons whose security are denied are overwhelmingly women. Such an analysis draws attention to the invasion and encourages one to feel the impact of its denial, to identify with the victim at the level of physical intervention and to suffer the indignity, fears and harms with her. Security of the person operates to make the violence and violation apparent and concrete, and reminds us that when the invasion is sexual assault, women's bodies, as well as their rights, are at stake.

Given that the physical costs exacted from women during forced sex often involve the threat or actuality of death, the restraint of liberty and the denial of security of the person, the constitutional values in s. 7 are highly relevant to the interpretation of the Criminal Code prohibition against sexual assault. In some respects, both are intended to protect similar interests. Stated positively as an entitlement, life, liberty and security of the person in the sexual context would mean that women would control their sexual availability and

Smart, supra note 46. If you are uncomfortable reading these words, just imagine the victim's distress in being forced to use them face to face with a person in authority.

49 C.A. MacKinnon, Feminism Unmodified: Discourses on Life and Law (London: Harvard University Press, 1988) at 86-87.

so Smart, supra note 46 at 39.

51 The Supreme Court's refusal to include a corporation within the term "everyone" in s. 7, reinforces the extent to which s. 7 is concerned with physicality. In Dywidag Systems Imt'l v. Zutphen Bros. Const., [1990] 1 S.C.R. 705 the Court reiterated the position taken in Irwin Toy Lid. v. A.G. Que., [1989] I S.C.R. 927 that a corporation cannot be deprived of life, liberty and security of the person and cannot therefore avail itself of the protection afforded by 5.7 of the Charter. 
their participation in individual acts of sex; women would be free to not engage in sex; and women would select for themselves the circumstances of agreed intimacy. ${ }^{52}$

\section{RELEVANT CHARTER RIGHTS: EQUALITY RIGHTS}

Although the lives, liberty and physical and mental security of women are in issue in the context of sexual assault, the constitutional questions are not only, or even primarily, those of individual rights and freedoms. An equality analysis is necessary because of the essentially gendered nature of crimes of sexual violence. In sexual assault, women are targeted for sex as a group because they are women. A focus on individual rights may fail to make the connections between the socially disadvantaged position of certain groups and how individual groups' members are treated. For example, an equality analysis helps make the point that sexual violence is essentially a sex specific, group-based phenomenon which occurs within a larger context of social inequality: it is not merely the personal problem of an individual woman. ${ }^{53}$

Two Charter sections raise equality considerations. First, s. 28 of the Charter is an interpretative provision and requires that every separate Charter right, including the guarantees in s. 7 , must apply equally to men and women. ${ }^{54}$ This means that women's

There is a widespread myth that women control access to sex - in fact, it is often argued to be a major source of power over men. It is simply not true. Socially, the expectation of many is that the male will act as intercourse initiator and sexual aggressor. The woman's role is to respond, not control. And her ability to reject is impaired by numerous factors - not the least of which is the widespread premise that women are supposed to be sexually available to men.

53 The gender dimension is therefore a critical acknowledgement. Under an equality analysis it is not an adequate response to women's unequal sexual victimization to suggest that we live in a violent society in which everyone fears for their physical safety. That may be true. But it would be improper to equate a man's fear of being "mugged" with a woman's fear of sexual violence. Statistically their incidence vary dramatically and both conceptually and practically they are not the same. The defining characteristic of sexual assault is that of sexual violence, where a woman is selected on the basis of her sex and for sex. To claim that sexual violence against women is merely a sad part of a disintegrating society is to restate the issue in a fundamentally incorrect, decontextualized and deceptive way.

We have witnessed just how readily a general justification can be invoked in relation to an event as recent and clear as the Montreal Massacre. Even though the murderer admitted, in writing, that he was motivated by his hatred for feminists, even though his sights were literally set exclusively on women, and only because they were women, there were still some people who were prepared to reinterpret his crime, deprive it of its defining characteristic, and sanitize its sexual element.

See supra note 5 . It is intended to be a binding interpretive norm even though its terms are not stated in expressly mandatory language. One author has suggested that properly understood it operates as the last paragraph to every other Charter section. See K.J. de Jong, "Sexual Equality: Interpreting s. 28" in A.F. Bayefsky \& M. Eberts, eds., Equality Rights and the Canadian Charter of Rights and Freedoms, (Toronto: Carswell, 1985) 493 at 522. It has also been likened to a "prism" which alters the scope and content of enumerated rights. See W. Pentney, "Interpreting the Charter: General Principles" in G.A. Beaudoin \& E. Ratushny, eds., The Canadian Charter of Rights and Freedoms, 2d ed. (Toronto: Carswell, 1989) 21 at 39. The commentators who have suggested that s. 28 "means and accomplishes nothing" or has "very little work to do" erroneously assume the gender neutral formulation and application of general legal provisions. See respectively E.A. Driedger, "The Canadian Charter of Rights \& Freedoms" (1982) 14 Ottawa L. Rev. 366 at 373 and P. Hogg, Constitutional Law in Canada, 2d ed. (Toronto: Carswell, 1985) at 802. 
right to life, liberty and security of the person must be equal to those enjoyed by men. Secondly, the Charter contains an independent and substantive guarantee of equality rights in s. 15. Section 15 mandates that women receive equality before the law, equality under the law, and the equal protection and benefit of the law. ${ }^{55}$ That the Charter now entrenches sexual equality as a legal standard of the highest priority should help redress whatever gender bias currently exists in sexual assault jurisprudence.

In Andrews, ${ }^{56}$ the Supreme Court said the purpose of $\mathrm{s} .15$ is to ensure equality in both the formulation and application of the law. Section 15 requires that "[c]onsideration must be given to the content of the law, to its purpose, and its impact upon those to whom it applies and also upon those whom it excludes from its application. ${ }^{.57}$ Equality determinations under the Charter require an understanding of "the context of the place of the group in the entire social, political and legal fabric of our society. ${ }^{158}$ In defining what equality means, the Supreme Court also recognized that discrimination may be systemic; that is, built into the foundations of existing practice, even if there is no intention to create or continue disadvantage. It has also rejected the limitations of an identical treatment equality paradigm, ${ }^{59}$ stating that true equality may require differential treatment if the burdens of the unfairly disadvantaged are to be alleviated. ${ }^{60}$

In Andrews, the Court also required discrimination before there could be a breach of s. 15. Discrimination is defined as:

a distinction, whether intentional or not but based on grounds relating to personal characteristics of the individual or group, which has the effect of imposing burdens, obligations or disadvantages on such individual or group not imposed upon others, or which withholds or limits access to opportunities, benefits, and advantages available to other members of society. ${ }^{61}$

Discrimination occurs when women, and not men, are made to suffer legal burdens on their rights because of their sex. The Court said:

The promotion of equality entails the promotion of a society in which all are secure in the knowledge that they are recognized at law as human beings equally deserving of concern, respect and consideration. It has a large remedial component. ${ }^{62}$

See supra note 5.

Supra note 10 at 171.

Ibid. at 168 .

Ibid. at 152. See W. Black \& L. Smith, "Comment" (1989) 68 Can. Bar Rev. 591; R. v. Turpin, [1989] 1 S.C.R. 1296.

Andrews, supra note 10.

R. v. Big M Drug Mart, supra note 13.

Supra note 10 at 174 . This definition was selected on the basis of its similarity with provincial, national and international human rights enactments. This test contains two separate strands. One relates to improperly imputing individual characteristics on the basis of group affiliation - the classic evil of stereotyping. The second strand, however, encompasses the treatment of groups and emphasizes the imposition of disadvantage even in the case of an attribute which members of the group actually possess. This second strand would operate to prohibit discrimination against women because of their biological capabilities.

Ibid. at 171. 
To truly ensure equal concern, respect and consideration the existence and extent of legal burdens should be measured from the complainant's perspective. ${ }^{63}$

In subsequent human rights cases, the Court has made it clear that discrimination need not be directed towards every woman before it qualifies as sex-based. In Brooks v. Canada Safeway Ltd., ${ }^{64}$ the Court concluded that there was sex-based discrimination when a company's insurance plan treated pregnant employees significantly less favourably than other employees. The Court reasoned that while pregnancy-based discrimination only affects part of the identifiable group of women, it does not affect anyone who is not a member of the group. The company's plan was, therefore, no less offensive because it did not discriminate against all women. The Court reasoned that such a plan not only unfairly disadvantaged pregnant women, it could "be viewed as a disadvantage suffered by women generally." ${ }^{165}$ The Chief Justice explained:

It would do so by sanctioning one of the most significant ways in which women have been disadvantaged in our society. It would sanction imposing a disproportionate amount of the costs of pregnancy upon women. Removal of such unfair impositions upon women and other groups in society is a key purpose of anti-discrimination legislation. ${ }^{66}$

In these comments the Chief Justice acknowledged the central role that reproductionrelated discrimination has played in the subordination of women and recognized that it should not be allowed to continue. Similarly, in Janzen \& Govereau v. Platy Enterprises, ${ }^{67}$ the Supreme Court held that the sexual harassment of only some female employees was still sex discrimination. The entire Court rejected the employer's argument that the harassed employees were treated differently only because of their sexual attractiveness and not their gender.

The Supreme Court's reasoning in these equality cases can be used in the context of sexual assault jurisprudence. The Court's approach to equality and discrimination suggest that even a gender neutral provision on sexual assault would raise sex equality issues because women are directly, disproportionately and disparately victimized. ${ }^{68}$ Sexual assault is a form of sex discrimination, even if not all women are assaulted, because women are disproportionately victimized. Women are selected as targets for sexual

Ibid. at 164. Whether something constitutes a benefit or burden depends largely upon whether the focus is on the person supposedly benefited or allegedly burdened. Under the Court's approach to equality, social conditions of disadvantage are more important than biological difference. In Andrews, Mr. Justice McIntyre remarked that equality "is a comparative concept, the condition of which may only be attained or discerned by comparison with the condition of others in the social and political setting in which the question arises." The social and political context was thus an important consideration. [1989] 1 S.C.R. 1219.

lbid. at 1238.

Ibid.

[1989] 1 S.C.R. 1252.

Andrews, supra note 10 at 171 . Mr. Justice McIntyre endorses the view that "s. 15(1) read as a whole constitutes a compendious expression of a positive right to equality in both the substance and the administration of the law." 
violence on the basis of their gender group and not on the basis of some unlisted ground like sexual attractiveness. According to existing case law, sexual violence against women emerges as both proof and practice of sex inequality.

Under an equality analysis, an understanding of women's overall position of disadvantage and their sex specific forms of oppression are necessary parts of the analysis because both characterize their social situation. In this regard, it is important to question the relationship between women's inequality and sexual assaults against them. Many authors explain how over time, and even now, the sexual victimization of women is one way men enforce the power imbalance of gender hierarchy. ${ }^{69}$ Sexual violence, described as the paradigmatic example of how men keep women in their place, operates to benefit all men - not just the individual who rapes or coerces for his own gratification. ${ }^{70}$ Susan Brownmiller claims that rape keeps all women afraid and makes all women more submissive and deferential to men. She claims that the purpose of rape from prehistoric times to the present is "nothing more nor less than a conscious process of intimidation by which all men keep all women in a state of fear." ${ }^{171}$ Susan Griffin outlines the social expectation that certain men, like husbands, are to receive sex in exchange for trying to keep "his" woman safe from other men. She likens this arrangement to a protection racket. ${ }^{72}$ Catherine MacKinnon explains that the rape of women operates as a form of

Although there are legal prohibitions which purport to outlaw sexual violence against women, there exist powerful financial and social institutions which support it. For example, in its quest for profits the multi-billion dollar pornography industry constructs ideas of sexuality in which women are defined as sex objects for male use. Pornography reduces a woman into a thing in such a manner that the woman on the page can be had by any man with the magazine's purchase price. Pornography creates and supports a social environment of sex inequality. Women have little say in how they are portrayed and until recently women were excluded from the community authorized to determine standards of tolerance in obscenity law. Not only are women unrepresented, their complex humanity is denied when women are dismembered into the body parts pornography conditions men to desire. Women are tied, bound, gagged, tortured, and even when covered with their own blood they are pictured as smiling throughout. The pornographers not only manipulate the woman's posture, they take away her voice and deny her right to dissent by making it appear as if she is enjoying what they are doing to her. Women realize that they live in a culture in which pornographic images of them are everywhere. They know it means that they have lost control over the circumstances in which they will be perceived as sexual beings.

There is a body of literature which outlines "man's sex right" - that is the composite package of privileges men have accumulated over the years. It is said to include the (usurpation of the) right to sex. See L.M.G. Clark \& D. Lewis, Rape: The Price of Coercive Sexuality (Toronto: Women's Press, 1977).

S. Brownmiller, Against Our Will: Men, Women and Rape (New York: Simon \& Schuster, 1975) at 5 .

S. Griffin, "Rape: The All-American Crime" (1971) 10 Ramparts 26. In her now classic article, she also considered and discarded certain rape myths. She criticized beliefs that all men who rape are crazy; that if it were not for learned social controls all men would rape; that rape is natural and universal; that men are expected to be aggressive, females remain passive while simultaneously holding that all women secretly want to be raped; that rape is provoked by the victim; that rape is enjoyed by the victim; that women deserve to be raped for acting as if they were free - the sexual double standard where only bad girls get raped; that a woman with a prior sexual history either could not be raped or should not be believed; that women vindictively and falsely accuse men of rape. She explained how the basic elements of rape are involved in all heterosexual relationships. This may explain why men often identify with the offender and not the victim. See also M. Rioux, When Myths Masquerade as Reality: A Study of Rape (Calgary: Advisory Council on the Status of Women, 1975). 
sexual terrorism which is "at once absolutely systematic and absolutely random systematic because women as a group are its targets and they live knowing it; random because there is no way of knowing which individual woman will be next on the list." ${ }^{173}$ Sexual violence against women helps create and maintain sex based inequalities.

The sexual use of women is thus a significant way in which women have been disadvantaged in our society and in which men have been unfairly advantaged. ${ }^{74}$ Under an equality analysis it is difficult to justify why a person accused of sexual assault was ever granted the benefit of special rules about recent complaint, warnings about corroboration and fishing expeditions into the prior sexual history of the victim in the first place. In an egalitarian society, it would be even more difficult to justify retaining any vestige of these unearned privileges. ${ }^{75}$

\section{APPLYING CHARTER RIGHTS TO SEXUAL ASSAULT}

The approach to individual rights and equality determinations which takes social context into account can, and in my view should, inform the formulation, interpretation and application of the legal concepts governing sexual assault. ${ }^{76}$ In most cases it can do so without improperly diminishing the rights of the accused. In the cases where a conflict emerges, a thoughtful balancing of all interests is necessary. The Charter rights of victims must be thoroughly canvassed and well understood. They should not be automatically trumped by the Charter rights of the accused.

MacKinnon, supra note 49 at 7.

P. McIntosh, "White Privilege: Unpacking the Invisible Knapsack" (July-August 1989) Peace \& Freedom 10. Women's general disadvantage and specific sexual victimization result from unacknowledged and existing systems of male privilege. She comments that while men are often willing to grant that women are disadvantaged, men are less likely to admit that they are overprivileged. But this is perhaps the next change or shift required in what Rosalie Abella has called the ongoing process of equality. See R. Abella, Equality in Employment (Ottawa: Minister of Supply and Services, 1984) at 2.

Many authors have argued that the primary preoccupation of previous rape laws was either to preserve a man's proprietary interest in his women (wives and daughters) or to foreclose the possibility of false accusations of rape against male accused. Clark \& Lewis, supra note 70; G. Parker, "The Legal Regulation of Sexual Activities and the Protection of Females" (1983) 21 Osgoode Hall L.J. 187; C.B. Backhouse, "Nineteenth Century Canadian Rape Law 1800-1892" in D. Flaherty, ed., Essays in the History of Canadian Law Vol. II (Toronto: U of T Press, 1983) 200. This is not to suggest that the "large and liberal" aspects of the purposive approach of the Charter should in any way displace the principle that criminal offences are interpreted narrowly and strictly. Even with statutory crimes it is recognized that the purpose of the prohibition is a key consideration in the interpretation of particular provisions. There is no one sacrosanct way to discern the purpose of a criminal prohibition. My suggestion is that, in seeking the evils the sexual assault sections were intended to address, we should recognize the sorts of contextual factors which currently inform Charter jurisprudence. This may lead to a greater conceptual consistency and compatibility between laws, a greater responsiveness of law to the real life conditions in which it operates and more gender inclusive norms. 


\section{A. A CASE STUDY}

A contextual analysis that takes women's Charter interests and life experiences into account can be expected to have a significant and salutary impact on the interpretation of current provisions. An example is the case of $R$. v. McCraw. ${ }^{7}$ McCraw was charged with uttering or conveying a threat to cause "serious bodily harm" contrary to $\mathrm{s}$. 264.1(1)(a) of the Criminal Code ${ }^{78}$ The accused sent letters to the homes of three cheerleaders in which he graphically described the sexual acts he claimed he would do to them. He told these women that he masturbated thinking about them every night. He continued: "I would shoot my sperm over your face. I am going to fuck you even if I have to rape you. Even if it takes me to the day I die." One victim received a second letter in the same envelope in which the accused told her to meet him at a specified time at a designated place. He warned her "if you don't show up I will go to Rockland [her home] and get you, don't forget I know where you live." The accused also knew where all three worked. The recipients testified that the letters frightened them to the extent that, in response, they modified their behaviour and restricted their movements; they related how they no longer felt safe when they were alone and they explained how they felt less free because of the threats against them. ${ }^{79}$

The primary legal issue was whether the threat to rape constituted a threat to "cause serious bodily harm." Even though the trial judge ${ }^{80}$ found that the statement was a threat of rape and was perceived by the complainants as a threat to rape them, he nevertheless concluded that a threat of rape would not always amount to serious bodily harm. He classified the letters in the following manner: "[t]he tenor of the letters, while immature and disgusting, reveal more of an adoring fantasy than a threat to cause serious bodily harm. ${ }^{81}$ This comment suggests that the trial judge preferred the perspective and intention of the man who sent the letters over the experience of the women who received them. ${ }^{82}$ In contrast, the majority of the Ontario Court of Appeal ${ }^{83}$ and the Supreme

Supra note 2. For comments see K. Mahoney, "R. v. McCraw: Rape Fantasies and Fear of Sexual Assault" (1989) 21 Ottawa L. Rev. 207; R. Sullivan, "Interpreting the Criminal Code: How Neutral Can It Be? A Comment on R. v. McCraw" (1989) 21 Ottawa L. Rev. 221; R. Wakefield, "A Comment on R. v. McCraw" (1989) 21 Ottawa L. Rev. 239.

R.S.C. 1985, c. C-46. It reads: "Every one commits an offence who, in any manner, knowingly utters, conveys or causes any person to receive a threat (a) to cause death or serious bodily harm to any person."

$R$. v. McCraw, supra note 2 at 520 .

80 Flanigan, D.C.J., as quoted in "R. v. McCraw: The Judgment" (1989) 21 Ottawa L. Rev. 201 at 203. Ibid. at 263.

It is quite clear that the letters were not received as either adoring or fantasies. In addition, there is the hint that a sexual fantasy is a specially protected category of human activity - somehow private, abstract, not real. A similar argument in a related context is that pornography is not harmful because it only involves images. While I have never understood this argument, it is clearly inapplicable on the facts of the McCraw case. The accused did not merely think these thoughts - he acted on them in very real ways and with very real consequences. Writing a letter and translating thoughts to paper is real, posting the letter is real, receiving the letter is real, reading the letter is real and the resultant fear is real. Another problematic feature of the trial judge's comment is the implication that the acts and activities the accused was going to do to these women, with or without their consent, could still qualify as adoring. This reflects a depressing, brutal and seriously one-sided notion of sexuality. 
Court of Canada held that these letters contained threats of serious bodily harm. Mr. Justice Cory found that "[t]his was not juvenile, puerile sexual fantasizing, it was a threat of grave violence intended to enforce compliance."

What explains the stark divergence between these two characterizations of the same letter? In my view, the primary difference is that the Supreme Court used the Charter rights of women as the prism through which they analyzed the prohibition in issue and the acts in question. Even though women's equality rights and their equal right to life, liberty and security of the person constituted no formal part of the Court's reasons and were not expressly cited in the judgment, an understanding of the social context of women's inequality and women's constitutional entitlements infused the judgment. The spotlight was not directly on women's Charter interests but they clearly illuminated the entire decision.

Mr. Justice Cory, writing for a unanimous Supreme Court, took women into account in numerous ways, considered the overall context of women's social and sexual disadvantage, and understood how women's generalized fear of sexual assault had become particularized through personally addressed letters to their homes. When considering the purpose behind the criminal offense of uttering threats, Mr. Justice Cory found that it was to protect against fear and intimidation. He formulated the following legal test:

Looked at objectively, in the context of all the words written or spoken and having regard to the person to whom they were directed, would the questioned words convey a threat of serious bodily harm to a reasonable person. 85

He expressly included women when ascertaining how the ordinary person would react, implicitly recognizing women as a separate gender class with sex-specific realities. ${ }^{86}$ Such a step is as encouraging as it is necessary because often in the past the reasonable man standard has been precisely that, male. Justice Cory also decided that a threat to rape was a threat of serious bodily harm because the ordinary reasonable person understands the word rape in that way, especially "bearing in mind that at least $50 \%$ of the ordinary reasonable people in our society are women. ${ }^{187}$ His express inclusion of women continued when he determined whether rape was serious bodily harm. He stated: "It seems to me that to argue that a woman who has been forced to have sexual intercourse has not necessarily suffered grave and serious violence is to ignore the perspective of women." 88 The Supreme Court's leadership in fashioning gender inclusive legal principles is a necessary part of the rethinking of rights, relevant considerations and outcomes required under the Charter.

Supra note 2 at 529.

Ibid. at 525 .

He held that "bodily harm" under s. 264.1 includes psychological harm which substantially interferes with the health or well-being of the complainant. There was a recognition that is also important in the context of sexual assault, that "[t]here can be no doubt that psychological harm may often be more pervasive and permanent in its effect than any physical harm." Ibid. at 524.

Ibid. at 527.

Ibid. at 526 . 


\section{B. SOME FURTHER THOUGHTS}

The Supreme Court's current approach to individual and group based Charter rights may have wide ranging implications for other aspects of sexual assault law. ${ }^{89}$ At a basic level, the shift in 1982 from the gender specific crime of rape to a gender neutral offence of sexual assault reflected Parliament's desire to conform to the Charter's sex equality guarantees. But the process of incorporating equality principles into the law on sexual assault requires more than using non-sexist language or creating an offence which could be committed by members of either sex. ${ }^{90}$ For example, the central, distinctive and distinguishing feature of an equality analysis is a consideration of the general power imbalance between men and women and its manifestation in individual cases.

Under current law, the presence or absence of consent differentiates sexual intercourse from sexual assault. Before Bill C-49, there were few legislative indications of how consent was to be approached and ascertained. ${ }^{91}$ The new law provides greater guidance.

An equality analysis helps remove sexual violence from an abstract and hypothetically equal world and situates it squarely within the context of social inequality. Although the narratives allowed by law are rather limited, and rules of evidence and procedure and principles of relevance restrain a full recounting of the complexity of people's lives, there is still some scope for using equality principles to put before the courts the realities of women's lives, as women see them. I also think that the forthcoming legislative changes to the sexual assault provisions in Bill C. 49 have employed women's Charter rights as their theoretical underpinning.

A contextual and equality-seeking approach makes us ask questions about how sexual violence against women has helped create and maintain sex-based inequality, forces us to canvass what interests were actually protected by previous laws on sexual assault, and raises the recurring debate over whether there is any proper place for evidence of the complainant's prior sexual history given the widespread acceptance of rape myths and erroneous gender stereotypes.

Bill C-49 is primarily a response to $R$. v. Seaboyer, supra note 7 and is now law (An Act to amend the Criminal Code (sexual assault) S.C. 1992, c. 38).

The Preamble expresses concern about sexual violence and abuse in Canada and its effect on the lives of Canadians, as well as the need to encourage reporting of sexual violence. It seeks a process that will be fair to both complainants and accused persons, particularly within ss. 7 and 15 of the Charter. It states that evidence of sexual history is rarely relevant and inherently prejudicial, and accordingly its admission should be subject to scrutiny. A new s. 273.1(1) defines "consent" as the voluntary agreement of the complainant to engage in the sexual activity in question. This is for the purposes of ss. 271 (sexual assault), 272 (sexual assault with a weapon), and 273 (aggravated sexual assault). S. 273.1(2) outlines situations where consent is not obtained, such as where (a) someone other than the complainant consents (by words or conduct); (b) the complainant is incapable of consent; (c) the accused induces the complainant to consent by abusing a position of trust, power or authority; (d) the complainant expresses a lack of agreement (by words or conduct); or (e) the complainant had consented to engage in sexual activity but expresses by words or conduct a lack of agreement to continue.

Under a new s. 273.2, the accused's belief that the complainant consented is not a defence where (a) it arose from the accused's (i) self-induced intoxication or (ii) recklessness or wilful blindness, or (b) the accused did not take reasonable steps, in the circumstances known to the accused, to ascertain whether the complainant consented.

The old s. 276 was a blanket exclusion of past history evidence, with three exceptions. Seaboyer said that this did not allow the court to properly determine relevance, and that relevant evidence may have been excluded as a result. The new enactment will not necessarily admit the evidence, since a voir dire will have to be held, but it allows the court to balance a variety of factors and decide whether or not the possible prejudicial effect of the evidence outweighs its potential value to the truth-finding process. The new $\mathbf{s}$. 276.1 states that the complainant's past sexual history is not admissible to support an inference that she (a) is more likely to have consented to the activity at 
However, it is very important that any legal standard of consent places events in their larger context to better understand the numerous powerful constraints which may operate on a woman's will. Women's social position and overall disempowerment should be important considerations in assessing whether there has been consent and/or coercion. ${ }^{92}$ For example, in our unequal society, women tend to be conditioned to a learned physical helplessness such that they are unlikely to think themselves physically able to ward off an attacker, to resist the violence with violence, or to succeed when they do. In many cases, the man is larger and the physical disparity alone counsels submission. ${ }^{93}$ Understanding this type of imbalance suggests that it is wholly inappropriate to measure the conduct and reactions of women victims against a male standard. The idea that a man would fight, scream, try to run away, etc., if confronted by like violence should be irrelevant, even if "like violence" in this context is possible.

Social context is also a key variable in determining the presence or absence of coercion. While certain forms of conduct are seen as obviously coercive, in many cases coercion is circumstantial. What will work and what is required will depend upon who is targeted. A person who uses coercion and manipulation to impose his will has usually gauged what he believes to be necessary to achieve his goal. A man seeking to coerce a physically bigger man will probably use a different strategy and level of force than if he was approaching a small child. The difference in size, authority and experience between

issue; or (b) is less credible. This subsection echoes McLachlin J. in Seaboyer, ibid. at 409. The new s. 276(2) provides that evidence of past sexual activity is not admissible unless the court determines that it (a) is of specific instances of sexual activity; (b) is relevant to an issue at trial; and (c) the probative value outweighs the potential for prejudice [this phrase also comes from McLachlin J. in Seaboyer]. The new s. 276(3) outlines the factors to be considered by the court in determining admissibility. The old s. 276 did not have this.

A new s. 276.1 outlines the procedure for the accused to apply to the court to determine if certain evidence is admissible. The old s. 276(2) required only that written notice of an intention to adduce certain evidence, and particulars of the evidence, be given to the prosecutor and clerk of the court.

A new s. 276.2 deals with the hearing procedure to determine admissibility. Like the old s. 276, the jury and public are excluded and the complainant is not compellable. Under s. 276.2(3), judges must give reasons for their decisions, which become part of the record.

A new s. 276.3 prohibits publication of information relating to the application and the determination of admissibility, unless the evidence is admissible or the judge permits publication.

A new s. 276.4 deals with the judge's instruction to jury over the use of such evidence.

It may also require a wider definition of the type of fraud which vitiates consent. Restricting fraud to either the nature or quality of the act and the identity of the accused is a very limited protection for women when they have been victimized by fraudulent inducements from individuals in positions of greater power. A. Bryant, "The Issue of Consent in the Crime of Sexual Assault" (1989) 68 Can. Bar Rev. 94 suggests that a "wide" interpretation of fraud would produce some remarkable results. Perhaps from the perspective of women, such a remarkable change is precisely what is required. Incorporating the perspective of the woman may even have an effect on bow the level of violence is classified. For example, to a woman the man's hands may be seen as weapons and his very action in taking control over her may be seen to endanger her life.

93 Most women, therefore, will not have a strategy of physical retaliation because of various social forces. For example, women tend to be socialized to be pleasant, cooperative, and supportive. If women's status is derivative and their physical security is dependent, they learn to be good at relationships and keeping the peace. For many women, pleasing a man is motivated more by their own preservation than either her affection or his gratification. Many women understand that men have the power to punish, to inflict violence, withhold funds, to control their lives and make it miserable in numerous ways. This may make women less likely or able to confront sexual aggression either at all or with the vehemence they may want to convey. 
the adult and the child, combined with the child's fear of sanctions and reprisal for noncompliance, means that little overt physical violence may be required for the adult to coerce the child into submission. These same factors must be taken into account when men seek to coerce women into sexual acts. Size differentials, power imbalances, the man's take-charge sexual aggressor role, under which he is likely to be absolved for initiating and pursuing sex irrespective of the woman's will, his socialization towards an acceptance of the use of physical force and the woman's fear that any resistance may be met with escalating force, all illustrate how power imbalance must inform what qualifies as coercion, even between adults.

In a recent civil case, the Supreme Court of Canada adopted this contextual approach and held that a drug addicted woman did not truly consent to sexual acts requested by the older male physician who illegally supplied her with drugs. In Norberg v. Wynrib, ${ }^{94}$ the woman claimed damages for acts she experienced as instances of sexual assault and which the defendant asserted were voluntary activities, knowingly agreed to. The Court noted that a position of relative weakness can interfere with a person's free will and that determinations of consent must involve an appreciation of the power relationship between the parties. At least in the contractual setting, the Court went on to state that consent will be considered to be legally ineffective if it can be shown that there was such a disparity that the weaker party was not in a position to choose freely. These observations from a civil context may have implications in criminal cases where consent and coercion are also in issue..$^{95}$

\section{CONCLUSION}

The Charter gives state actors the opportunity and mandate to make laws more responsive to the various realities of women's lives. Even this brief review of women's constitutionally entrenched rights and sexual assault laws conveys the disparity between constitutional theory and social and sexual practice. Charter claims to equality and equal life, liberty and security of the person are presently at variance with women's everyday fear of assault, fear in the assault and fears of the response of the criminal justice system to the assault. In the future, these same Charter rights will be used to interpret, support and possibly challenge the laws which seek to shelter women from the sexual violence they are forced to experience and conditioned to fear. In formulating the content of these rights and applying them in the context of women's disproportionate sexual victimization, state actors are reminded of the challenge and necessity of including women fully in the fold of constitutional protections, of recognizing women-specific realities as equally meritorious and fashioning gender inclusive norms of justice.

95 Even though Norberg was a civil case, it dealt with the intentional tort of battery. Consequently, there may be greater parallels with the criminal concept of assault than would otherwise arise with a civil claim involving negligence or a contract action. In addition, the Criminal Code distinguishes consent from submission in a way that a criminal court may raise similar issues and will likely be influenced by these factors considered in Norberg. In a criminal case the Supreme Court employed a similar analysis when it held that for public policy reasons there are some legal limits to what an individual may consent to. See $R$. v. Jobidon, [1991] 2 S.C.R. 714 where the Court held that persons who engage in fights cannot consent to having death inflicted on them. 